Finanse, Rynki Finansowe, Ubezpieczenia nr 4/2018 (94), cz. 1

DOI: $10.18276 /$ frfu.2018.94/1-27

s. $311-318$

\title{
The scope of the use of shared services centre in Polish communes
}

\author{
Monika Kaczurak-Kozak*
}

\begin{abstract}
Purpose - Getting an answer to the question whether shared services centres created in Polish communes after the change of the political system are, in fact, a new solution in comparison to previously functioning teams of educational units service.

Design/methodology/approach - Literature study, analysis of legal regulations, analysis of source documents and reasoning.

Findings - Shared services centres gained recognition within the sphere of Polish local government activities, however, they are not used efficiently enough. Communes, in general, create shared services centres based on previously functioning teams of educational units service and focus mainly on servicing these units.

Originality/value - The research outlined current nature of a common service in Polish communes. Its results may provide the basis for further analysis that seeks an answer to the question on the reasons for the lack of a wider application of shared services centres in Polish local government activities.
\end{abstract}

Keywords: commune, common service, shared services centre, team of educational units service

\section{Introduction}

Since 1 January 2016, in Poland a common service has been made possible to be organised in a commune for both its organisational units and commune corporate entities. The foundation for common service is defined in article 10a-10d added to an Act on Commune Self-government (Act, 1990). Similar provisions have been introduced in districts and provinces. It means that for each local government unit an opportunity of common service has been ensured. It has to be noted that this common service, however, is not obligatory. Entities performing service tasks for other units and existing within one organisational structure are generally referred to as shared services centre (SSC). In local government acts, the organisational units providing common service are referred to as serving entities. Neither has a legislator established a legal form in them nor indicated a closed catalogue of implemented tasks as well, which indicates a far-reaching freedom in this area.

Until now common service existed only with regard to defined organizational units of a local government. The common service was possible, among others, in relation to

* dr Monika Kaczurak-Kozak, Branch Department in Sulechów of the University of Zielona Góra, e-mail: m.kozak@poczta.onet.pl. 
community schools and educational institutions. The communes created educational units service team which provided the administrative, financial and organisational management of schools and educational institutions functioning within their territory. Common service in such a form could have been conducted until 31.12.2016.

The aim of this article is to establish the factual state in the area of providing common service by Polish communes by verifying whether these new dimension serving entities are, in fact, previous educational units service team. Shared Service Centres functioning in Polish communes have never been analysed against the educational units service teams existing in Poland since 31.12.2016. The achievement of the defined objectives was supported by empirical research within which the analysis of source documents was performed. 54 resolutions on common service of organisational entities in the Łódź Province have been analysed. The choice of the area was random. All the analysed communes adopted the above mentioned resolution either in 2016 or 2017 . The choice was not influenced by any other criteria. The applied research methods also include literary studies, analysis of legal regulations and reasoning.

\section{Common service in a local government in a new form}

Shared services centres are used worldwide in the operations of private companies. This solution has been successfully implemented into a public sector and is commonly used in, among others, Great Britain, Holland, Finland, Canada, the United States and Australia. Some centres may compete with the ones functioning in the private sector (Czepelak, 2016, p. 39).

The market for shared services centres is developing dynamically in Poland as well. In 2010 there were 54 of them while in 2014 already 165 (Jarzyński, 2011, p. 24; Górecki, 2014, p. 12). The first shared services centre in the private sector in Poland, modelled after market solutions, was established within the Chancellery of the Prime Minister of Poland in 2010 (from 2017 Service Centre for Government Administration). There was also a chance to lead a common service in the local government sector. It was, however, limited to certain units only. Its scope and the units included into common service are presented in Table 1.

Since 1 January 2016 the scope of common service, presented in table 1, has been extended. The possibility of a common service has been introduced at commune ${ }^{1}$ level for:

- commune organisational units included into the public finance sector,

- commune cultural institutions,

- other, included into the public finance sector, communal corporate entities created on the basis of separate acts in order to perform public tasks, excluding enterprises, research institutes, banks and commercial law companies.

1 Equivalents of the provisions at a lower level, i.e. regarding communes apply at district and provincial level. 


\section{Table 1}

The objective and subjective scope of a common service in local government units in 2016

\begin{tabular}{lll}
\hline Legal basis & $\begin{array}{l}\text { The form and scope } \\
\text { of a common service }\end{array}$ & Units included into a common service \\
\hline $\begin{array}{l}\text { The act on the education system } \\
\text { (art. } 5 \text { item 9) }\end{array}$ & $\begin{array}{l}\text { creating a finance } \\
\text { entity of schools and } \\
\text { educational institutions } \\
\text { organising a common } \\
\text { administrative financial } \\
\text { \& organisational service }\end{array}$ & $\begin{array}{l}\text { schools, kindergartens and } \\
\text { establishments, i.e.: establishments } \\
\text { of education \& care, of continual and } \\
\text { practical education, art facilities, } \\
\text { institutions of vocational development } \\
\text { \& training, psychological } \\
\text { \& pedagogical counselling centres, } \\
\text { educational libraries }\end{array}$ \\
\hline $\begin{array}{l}\text { The act on child custody up to } \\
\text { the age of } 3 \text { (art. 9a item 1) }\end{array}$ & $\begin{array}{l}\text { organisation of common } \\
\text { administrative financial and } \\
\text { organisational service }\end{array}$ & $\begin{array}{l}\text { nurseries, day-care facilities or their } \\
\text { complex facilities }\end{array}$ \\
\hline $\begin{array}{l}\text { The act on family support and } \\
\text { the foster care system (art. 18a } \\
\text { item } 1 \text { and art. 94 item 1) }\end{array}$ & $\begin{array}{l}\text { organisation of common } \\
\text { finance \& administration and } \\
\text { organisational service }\end{array}$ & $\begin{array}{l}\text { day-support centres, educational care } \\
\text { facilities }\end{array}$ \\
\hline
\end{tabular}

Source: own elaboration.

The entities entitled to a common service have been labelled as entities being served by a legislator who, with the reference to the aforementioned entities, indicates in a resolution by whom and in what kind of scope they will be served.

The shared services centre has not been defined by the Polish legislation. It has only been indicated that a serving entity may include: commune office, another organisational unit of a commune, organisational unit of communes union or an organisational unit of district \& commune union (Act, 1990, art. 10b item 1).

The aim to include the units functioning in a given local government structure into a common service is to increase independence and flexibility of local government units (Justification..., 2015). The ability to introduce a common service is to result in liberalising the functioning principles of non-corporate local government units which, even with small employment (a few persons) need to have their own financial plan, own accounting policy, chief accountant, act as an employer and payer of income tax and social insurance premiums (Guidelines..., 2013, p. 4).

\section{Creation of SSC vs. educational units service team (EUST) - the research results}

Shared accounting \& administrative service implemented by educational units service team (further EUST) functioned in many Polish communes. Their function was similar to SSCs. According to data, over $46 \%$ of communes in Poland created school finance \& administration boards (Justification..., 2015), which indicates the wide application which SSCs may 
have. It should be highlighted that SSC is to be seen as a chance to increase the efficiency of functioning structures and to adjust them to the needs and conditions of a given local government unit (Kiełbus, 2016, p. 26).

The records of the department of public administration of the Ministry of Interior and Administration concerning SSC as an element of rationalisation for the actions of local government administration indicate that SSCs were created in quite a large number of communes. They already function in more than a thousand communes (out of 2 thousand units that passed the information to the department) (Kancelaria Sejmu, 2017). It can be assumed that most communes where EUSTs used to function will create SSCs based on them. Does it actually happen? Do communes, by creating SSC, go beyond educational area and therefore pursue the objective established by the Polish legislation? The answer to these questions requires an analysis of resolutions adopted in the communes in this regard.

The research included 54 communes of Łódź Province which constituted about $30 \%$ of all communes in this province ${ }^{2}$. Applied research technique included the analysis of resolutions on a common service of organisational entities adopted in 2016-2017. The objective of the conducted research was to provide answers to the following questions:

1. Did EUST use to function in a commune before the creation of SSC?

2. Does subjective scope of common service within SSC correspond with the scope of service of EUST?

The results of the analysis are included in table 2 .

\section{Table 2}

The results of the analysis

\begin{tabular}{lllll}
\hline & The & The communes & The entities included into service within SSC \\
\cline { 3 - 4 } & $\begin{array}{l}\text { communes } \\
\text { which created } \\
\text { SSC }\end{array}$ & $\begin{array}{l}\text { in which EUST } \\
\text { used to function }\end{array}$ & $\begin{array}{l}\text { only educational } \\
\text { entities }\end{array}$ & $\begin{array}{l}\text { educational entities and } \\
\text { entities outside educational } \\
\text { system }\end{array}$ \\
\hline No. of communes & 54 & 41 & 36 & 18 \\
\hline
\end{tabular}

Source: own elaboration.

On the basis of the analysis of resolutions it turns out that $76 \%$ of communes ${ }^{3}$ in which EUST used to function, created a common service in a new form. Shared services centres include mainly a definitively educational area of a commune activity. It can be said that present SSCs derive from entities serving schools and other educational facilities before. It is also indicated by a character of entities included in common service. In $67 \%$ of analysed

\footnotetext{
2 According to Central Statistical Office there were 177 communes (urban, rural and urban \& rural communes) in Łódź Province in 2016.

3 The percentage of communes may be higher due to the fact that there are some interpretation uncertainties in the matter of ,transferring” EUST into SSC. We can come across different views in this field (Misiejko, 2016; Andruszkiewicz, 2017). Exemplary solutions include: adjusting the existing EUSTs by changing of statute, liquidation of EUSTs.
} 
SSCs the entities being served included only schools (primary schools, middle schools and complexes of schools) and kindergartens. In some communes SSC was created, based on EUST extending its service upon the entities functioning outside the system of education. Entities included into a common service - besides educational entities - mostly belong to: social welfare centres (12 communes), nurseries (4 communes) and municipal communities (2 communes).

The scope of a common service in the objective dimension (similarly to the subjective one) is an autonomous decision of the commune creating SSC. It can define the specialization area of serving entity. A common service can also include various areas of local government activities. A legislator pointed, in general, to ensure common service, especially administrative, financial and organizational one. Local government units only adjust its frames to their needs but some powers of a head of unit cannot be included into common service. These are:

- administering of public funds,

- incurring liabilities,

- preparing and approving a financial plan and transferring expenses in this plan (Act, 1990, art. 10c).

Activities of organisational or adjustment character that are the effect of the aforementioned powers can be transferred to be included into a common service.

Educational units service teams constituted - as the research shows - the foundation for the creation of SSCs in communes. In that case was the scope of tasks previously implemented by EUST reproduced in a new structure? By comparing article 10a of the act on commune self-government, in which an administrative, financial and organizational service was detailed, and article 5 item 9 of the act on the education system (Table 1), a positive answer should be expected.

The analysis of the scope of tasks included in the researched resolutions clearly indicates that SSCs mostly provide financial and administrative services ${ }^{4}$. A common service most often includes accounting service tasks. SSCs, appointed by communes, carry out the following tasks, ensuring a financial service (on the basis of resolutions' analysis):

- keeping accounts in accordance with the regulations,

- organising and conducting bank and cash services,

- preparing budget reports, statements on financial operations and other required by legal provisions,

- managing a payroll service of entities being served,

- carrying out settlements with a tax office and the National Insurance Institution,

- managing the Employee Benefit Fund,

- carrying out cash dispositions ordered by the heads of entities being served.

Presented catalogue of tasks for implementation by SSCs in fact coincides with the tasks previously carried out by EUST 5 .

\footnotetext{
4 In case of 3 communes it was accounting service only.

5 The tasks entrusted to SSCs in the analysed resolutions include also other issues, such as administrative $\&$ organisational matters, which vary significantly and were not the subject of the analysis.
} 


\section{The question of entrusting duties in the field of accounting}

Polish legislator, referring to the scope of a common service, distinctly indicated (Act, 1990, art. 10c item 2) that in the case of entrusting duties in the field of accounting and reporting of entities being served they are transferred in full. Therefore it is unacceptable to detail given activities of this scope (as opposed to the other transferred activities). It is possible, however, to specify them (Karciarz, 2016, p. 56).

The accounting range for an entity results from article 4 item 3 of the accounting act (Act, 1994). It should be applied separately for each entity being served. Moreover, a serving entity also keeps its own accounts. Previous legal regulations led to disagreements between the head of EUST and the principal of a school or education institution being served over vested powers and duties. The regulations allowing for a common service have been correlated with the entries in other legal acts (the act on public finances, the accounting act), determining the principles for the division of responsibilities between the head of an entity being served and the head of a serving entity (Andruszkiewicz, 2017, pp. 203-204). As practice has shown, the issues of precise and correct transfer of duties within a common service and accountability for them still cause problems. The doubts of employees of Polish local governments are raised by the issues of defining the accounting policy \& carrying out an inventory and taking responsibility in this field. Not establishing the accounting policy and inventory instructions by a head of SSC are the examples of common incorrectness (Galarda, 2017, pp. 53, 56).

\section{Conclusions}

The conducted analysis indicates that SSCs generally derive from entities formerly serving educational units. The dominance of these units in the sphere of currently implemented services makes one think that SSC remains for now a widely unused form. It should be remembered though that the new style of SSCs was first formed in Poland only 2 years ago. As a rule, new things often cause concerns and raise doubts. However, W. Lachiewicz (2016, p. 192) indicates that all concerns and risks connected with the implementation of SSCs should be considered only in subjective meaning, as errors in SSCs organisation. The research was of an indicative character and partially explained the nature of SSC activity. It neither exhausts the topic nor gives basis for a generalised assessment. A detailed analysis would need to be done considering the basis for a decision of local governments to organise a common service. It would allow to indicate the reasons for the findings.

The fact that the new solutions have been adopted in many Polish communes should be considered satisfactory. In practice, there are local governments which successfully implemented them, whereas the applied solutions are not uniform. The creation of SSC should be viewed through the prisms of local needs and problems. It is essential to adjust it to its own structure and goals to be achieved. SSCs are expected to develop and find their place in the structures of local government units in Poland. 


\section{Literature}

Act of 8 March 1990 on Commune Self-Government. Journal of Laws of 2017, item 1875 as amended.

Act of 7 September 1991 on the System of Education. Journal of Laws of 2015, item 2156 as amended.

Act of 29 September 1994 on Accounting. Journal of Laws of 2017, item 2342 as amended.

Act of 4 February 2011 on Child Custody Up to the Age of 3. Journal of Laws of 2016, item 157 as amended.

Act of 9 June 2011 on the Family Support \& Foster Care System. Journal of Laws of 2017, item 697 as amended

Andruszkiewicz, A. (2017). Usługi wspólne w oświacie. In: Samorządowe centra usług wspólnych, eds. M. Sakowska-Baryła, M. Górski (pp. 199-214). Warsaw: Municipium.

Czepelak, Z. (2016). Możliwości racjonalizacji kosztów działania placówek oświatowo-wychowawczych. In: Zarządzanie w jednostkach samorządu terytorialnego. Wybrane aspekty, ed. I. Wieczorek (pp. 37-62). Wrocław: Wydawnictwo Uniwersytetu Wrocławskiego.

Galarda, D. (2017). Samorządowe centra usług wspólnych. Biuletyn Informacyjny RIO w Bydgoszczy, 1, 33-58.

Górecki, J. (2014). Charakterystyka sektora nowoczesnych usług biznesowych w Polsce. In: Sektor nowoczesnych ustug biznesowych w Polsce 2014. Raport przygotowany przez Związek Liderów Sektora Usług Biznesowych (ABSL). Warsaw.

Guidelines to the Bill of 16 January 2013 on Improving the Terms of Providing Services by Local Government Units. Retrieved from: https://legislacja.rcl.gov.pl/projekt/101294 (10.02.2018).

Jarzyński, W. (2011). Centra usług wspólnych po polsku. Outsorcing Magazine, 1 (27), 24-28.

Justification for the Guidelines to the Bill of 25 June 2015 on the Change of the Act of Commune Self-Government and Some Other Acts. Journal of Laws of 2015, item 1045.

Kancelaria Sejmu (2017). Petny zapis przebiegu posiedzenia Komisji Samorzadu Terytorialnego i Polityki Regionalnej Nr 174 dated 22.11.2017. Biuro Komisji Sejmowych. Retrieved from: http://orka.sejm.gov.pl (2.02.2018).

Karciarz, M. (2016). Zakres działania samorządowych centrów usług wspólnych. In: Prawne aspekty organizacji i funkcjonowania samorządowych centrów usług wspólnych, eds. K.M. Ziemski, I. Wieczorek (pp. 39-66). Łódź: Wydawnictwo Uniwersytetu Łódzkiego.

Kiełbus, M. (2016). Cele tworzenia samorządowych centrów usług wspólnych. In: Prawne aspekty organizacji i funkcjonowania samorządowych centrów usług wspólnych, eds. K.M. Ziemski, I. Wieczorek (pp. 19-30). Łódź: Wydawnictwo Uniwersytetu Łódzkiego.

Lachiewicz, W. (2016). Centralizacja a reedukacja kosztów. In: E. Garczarek, Samorządowe centra ustug wspólnych. Tworzenie i funkcjonowanie (pp. 191-192). Warsaw: C.H. Beck.

Misiejko, A. (2016). Funkcjonowanie samorządowych centrów usług wspólnych w kontekście działania zespołów obsługi ekonomiczno-administracyjnej oraz centrów administracyjnych. In: Prawne aspekty organizacji i funkcjonowania samorządowych centrów ustug wspólnych, eds. K.M. Ziemski, I. Wieczorek (pp. 199-210). Łódź: Wydawnictwo Uniwersytetu Łódzkiego.

\section{ZAKRES WYKORZYSTANIA CENTRUM USEUG WSPÓLNYCH W POLSKICH GMINACH}

Streszczenie: $\mathrm{Cel}$ - Uzyskanie odpowiedzi na pytanie, czy centra usług wspólnych tworzone w polskich gminach po zmianie przepisów ustrojowych to w istocie nowe rozwiązanie na tle funkcjonujących dotychczas zespołów obsługi jednostek oświatowych.

Metodologia badania - Studia literaturowe, analiza regulacji prawnych, analiza dokumentów źródłowych oraz wnioskowanie.

Wynik - Centra usług wspólnych znajdują uznanie w sferze działań polskiego samorządu terytorialnego, lecz nie są dostatecznie wykorzystywane. Gminy generalnie tworzą centra usług wspólnych na bazie funkcjonujących wcześniej zespołów obsługi jednostek oświatowych i skupiają się głównie na obsłudze tych jednostek. 
Oryginalność/wartość - Badanie zarysowało aktualny charakter wspólnej obsługi w polskiej gminie. Jego wyniki mogą stanowić bazę do dalszych analiz, poszukujących odpowiedzi na pytanie o przyczyny braku szerszego zastosowania centrów usług wspólnych w polskiej praktyce samorządowej.

Słowa kluczowe: gmina, wspólna obsługa, centrum usług wspólnych, zespół obsługi jednostek oświatowych

\section{Citation}

Kaczurak-Kozak, M. (2018). The scope of the use of shared services centre in Polish communes. Finanse, Rynki Finansowe, Ubezpieczenia, 4 (94/1), 311-318. DOI: 10.18276/frfu.2018.94/1-27. 